\title{
THE IMPORTANCE OF A STRATEGIC PARTNERSHIP FOR BILATERAL RELATIONS
}

\author{
Milan Kankaraš, Ivan Petrović \\ Republic of Serbia, Ministry of Defence, Belgrade \\ Neven Cvetićanin \\ Republic of Serbia, Institute of Social Sciences, Belgrade \\ Vlada Mitić \\ Republic of Serbia, Ministry of Defence, Belgrade
}

\begin{abstract}
This paper aims to determine a way how to assess the impact of a strategic partnership on bilateralism and check that impact. In that sense, the strength of strategic partnership influence on bilateralism areas has been probed. In order to check the impact the research has been conducted on the case of the strategic partnership between the Republic of Serbia and six countries. Under those circumstances, different methods have been applied: expert-based evaluation method, DEMATEL (Decision Making Trial and Evaluation Laboratory Method) and statistical method. Some data has been collected by a survey questionnaire on 15 specialists, but the main data is accurate data from statistical yearbooks. There are two general results of this research. One of them is the model of the assessment of the strategic partnership impact on bilateralism. The second result is the confirmation of the strategic partnership impact on bilateralism. That impact varies from zero to perfect impact depending on a strategic partner and bilateralism area. The original purpose of the model is to assess bilateralism and the strategic partnership impact. In addition, the model is multipurpose and can be used to assess different relationships in public and private sector. The research results can help to understand cooperation in general and relationship between different areas. This study extends prior researches by examining the comprehensive process of bilateralism scope assessment. On the basis of the research results, implementation of the comprehensive process has been confirmed and improved.
\end{abstract}

Key Words: bilateralism, DEMATEL, expert-based evaluation, strategic partnership

\footnotetext{
* This paper is the result of the project number VA-DH/3/17-19 "Calculation of Long-term Financial Sustainability of the Duty Forces of Air Defence System of Serbian Armed Forces in Performing the Airspace Control and Protection in Peace". The Ministry of Defence of the Republic of Serbia funds the project.
} 


\section{Introduction}

The main human characteristic is sociability, which enables the cooperation between people and establishment of human societies. One of human societies is a state. The state can be expressed as a compulsory political organization with a centralized government that maintains a monopoly of the legitimate use of force within a certain geographical territory (Cudworth, et al., 2007). Bearing in mind that states consist of people, the cooperation between them is inevitable.

There are more than 190 states in the world (Nations, 2018) and they should maintain and develop relations with numerous countries. One of very important ways of relationship between countries is bilateral cooperation - bilateralism. In order to increase bilateral cooperation, countries sign strategic partnership agreements. Currently, there are numerous agreements such as the Strategic Partnership Agreement between Canada and the European Union (2016), the Strategic Partnership Agreement between the European Union and Japan (Gilson, 2016), etc. By signing the agreement, improvement in all bilateralism areas is expected.

However, the improvement is usually different both in terms of total bilateralism and bilateralism areas. Bearing in mind the abovementioned, there are miscellaneous opinions such as the strategic partnership is significant to bilateralism; the strategic partnership is irrelevant to cooperation, etc. In that sense, the research has been organized with the aim to determine a way how to assess the impact of strategic partnership on bilateralism and check that impact.

Besides introduction and conclusion, this paper includes three chapters. The methodology chapter describes and elaborates the implemented methods. The methods have been used on the case of the strategic relationship between the Republic of Serbia and six countries. It has enabled the data for the conclusion. The last chapter, the research results, has inferred the confirmation of the strategic partnership impact on bilateralism.

\section{Methodology}

The research problem is complex and it requires selection and implementation of various methods. In such case, the research is conducted through two stages: bilateralism scope assessment and the ascertainment of the strategic partnership influence. Both phases enable the usage of different methods and improve the quality of research.

In order to assess bilateralism scope the comprehensive process is applied. Kankaraš et al. (2017) have proposed the process, which enables combining brainstorming, expert-based evaluation method, DEMATEL and statistical method. In addition, the process is dynamic, and there is a possibility of amalgamating other methods. The comprehensive process contains four phases: data requirement creating, overall scope assessment, overall scope presentation and required checking results (Figure 1). 
The importance of a strategic partnership for bilateral relations

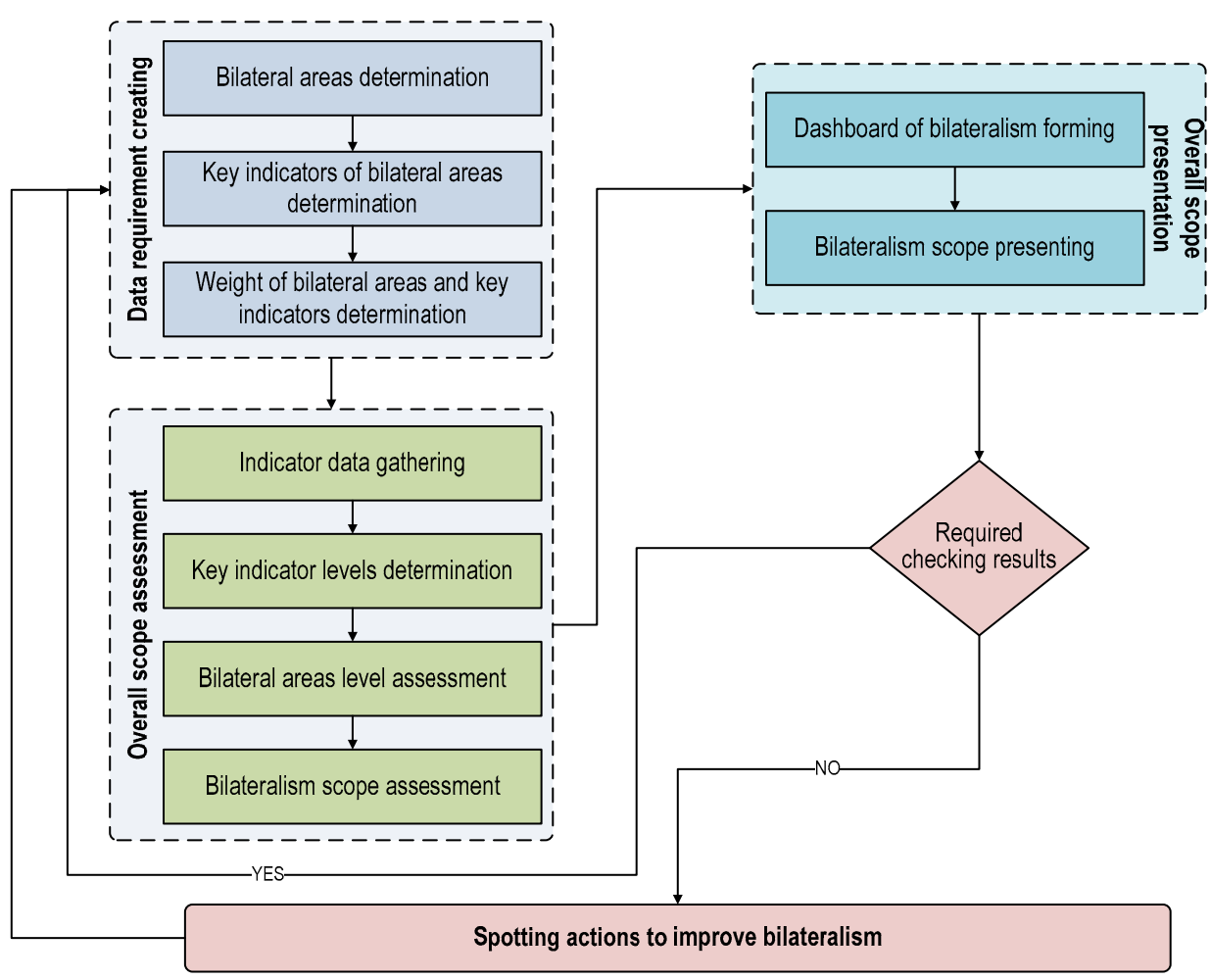

Figure 1 - The comprehensive process (Kankaraš, et al., 2017)

The process begins with determination of bilateral areas and their key indicators. In that sense, DEMATEL is the appropriate method, which enables determination based on mutual influence of bilateralism areas. The first step is creating an average matrix of experts' opinion (Wu, et al., 2007; Yang, et al., 2008; Yi Wu, 2012.; Moghaddam, et al., 2010; Kankaraš, et al., 2017). Each expert assesses the degree of direct influence between two bilateralism areas based on pairwise comparison. There are several scales to estimate the degree, but the most frequently used one is the five-step scale: 0 - no influence, 1 - low influence, 2 - medium influence, 3 - high influence, and 4 - very high influence (Sumrit, et al., 2013). Based on the individual experts' judgment $\left(a_{k r}\right)$, average individual experts' opinion $\left(\bar{a}_{i j}\right)$ is calculated by equation 1 , and an average mutual influence assessment matrix is created $(A ́)$ by equation 2 .

$$
\bar{a}_{i j}=\frac{1}{n} \sum_{r=1}^{n} a_{k r}
$$

and

$$
\bar{A}=\left[\bar{a}_{i j}\right]
$$


The key bilateralism areas are determined on the basis of total relation between them. In that sense, a matrix of total relation $(A)$ is calculated by equation 3 . (Moghaddam, et al., 2010)

$$
A=\hat{A}(I-\hat{A})^{-1}
$$

The elements of the normalized matrix $(A ́)$ are represented as a ratio of each element average mutual influence assessment matrix and the maximum amount of rows and columns (Sumrit, et al., 2013). In the last step, it is required to calculate a level of significance ( $\alpha$ - threshold value) as an average value of all total relation matrix elements (Yang, et al., 2008). The key bilateralism areas are determined on the basis of the threshold value. The value of total relation matrix element greater than the threshold value is more significant, representing the key bilateralism areas. In relation to the level of significance, threshold can be performed as experts' agreement or quartile. Bilateral areas, which have all elements less than the threshold value, should be rejected.

As it has been mentioned, each bilateralism area consists of the required number of indicators and the key indicators are determined in the same way in the second step. However, the key indicators are not the same - the level of significance to bilateralism areas is different (for instance, the total external trade balance is potentially more significant than the number of tourists). The significance level can be solved by the determination of key indicators' weight as a ratio of total impact of the current bilateralism area's indicator $(r)$ and the sum of total impact of the current bilateralism area's indicators equation 4 (Kankaraš, et al., 2017).

$$
w_{i}=\frac{r_{i}}{\sum_{i=1}^{n} r_{i}}
$$

The determination of bilateralism areas, their key indicators and indicators' weight are inputs for the second phase of the comprehensive process - overall scope assessment. Firstly, it is required to gather the value of indicators and determine indicator levels. However, there are difficulties because of indicator values expression (indicator values might be expressed in a quantitative or qualitative manner). Furthermore, quantitative value can be expressed as different measuring units (currencies, volume measures, surface measures, etc.) or different numbers (cardinals, fractions, decimals, percentages, etc.), while qualitative value can be expressed as assertion (yes, no, etc.) or description. Under those circumstances, the usage of indicator values to assess overall bilateralism scope needs some adjustment. Quantitative indicator values can be made suitable by normalization of their values $\left(\bar{I}_{i}\right)$ - Equation 5 (Petrovic, et al., 2017; Kankaraš, et al., 2017).

$$
\bar{I}_{i}=\frac{I_{i}-I_{\text {imin }}}{I_{\text {imax }}-I_{\text {imin }}}
$$

However, qualitative indicator value should be transformed by the linear numerical scale $(0-1,1-10$, etc.) In this research, qualitative values have been transformed in range 0-1 (Figure 2). 
The importance of a strategic partnership for bilateral relations

Figure 2 - The linear numerical scale for transformation (Kankaraš, et al., 2017)

\begin{tabular}{|c|c|c|c|c|c|c|c|c|c|}
\hline 0.1 & 0.2 & 0.3 & 0.4 & 0.5 & 0.6 & 0.7 & 0.8 & 0.9 & 1.0 \\
\hline $\begin{array}{l}\text { De- } \\
\text { scrip- } \\
\text { tion A }\end{array}$ & $\begin{array}{l}\text { De- } \\
\text { scrip- } \\
\text { tion B }\end{array}$ & $\begin{array}{l}\text { De- } \\
\text { scrip- } \\
\text { tion C }\end{array}$ & $\begin{array}{l}\text { De- } \\
\text { scrip- } \\
\text { tion D }\end{array}$ & $\begin{array}{l}\text { De- } \\
\text { scrip- } \\
\text { tion E }\end{array}$ & $\begin{array}{l}\text { De- } \\
\text { scrip- } \\
\text { tion F }\end{array}$ & $\begin{array}{l}\text { De- } \\
\text { scrip- } \\
\text { tion G }\end{array}$ & $\begin{array}{l}\text { De- } \\
\text { scrip- } \\
\text { tion H }\end{array}$ & $\begin{array}{l}\text { De- } \\
\text { scrip- } \\
\text { tion I }\end{array}$ & $\begin{array}{l}\text { De- } \\
\text { scrip- } \\
\text { tion J }\end{array}$ \\
\hline
\end{tabular}

Based on the assessed level, key indicators, bilateralism areas and overall bilateralism scope have been divided into three zones (normal, caution and critical) between minimum value ( $m v)$ and adequate value (av). Minimum value expresses the lowest acceptable value and any value less than that requires urgent action (Kankaraš, 2016; Kankaraš, et al., 2017). One of the possible ways is shown in Figure 3.

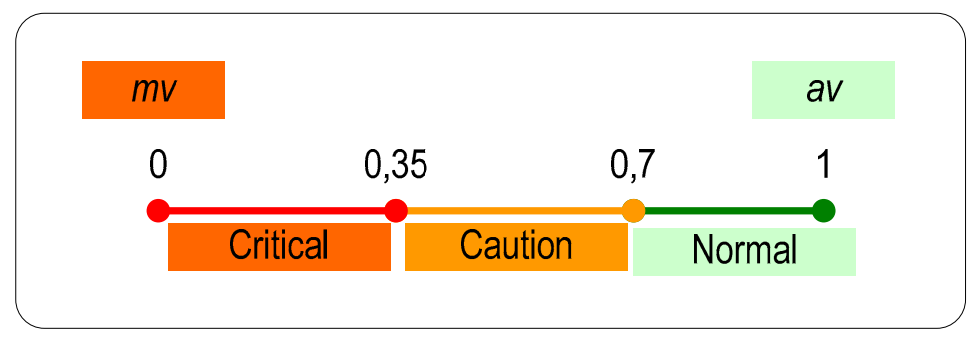

Figure 3 - Satisfactory value (Kankaraš, et al., 2017)

Key indicator level $\left(I_{l}\right)$ has been determined by equation 6 as a ratio of the difference between indicator level and minimum value and the difference between maximum and minimum value (Kankaraš, 2016; Kankaraš, et al., 2017).

$$
I_{l}=\frac{I_{i}-m v}{a v-m v}
$$

Such an approach enables the direct usage of the indicators value regardless of how they are expressed and in which measuring units. Hence, assessment of the bilateral area level $\left(B A_{l}\right)$ is simple - the sum of the indicators level and their weights multiplication (equation 7).

$$
B A_{l}=\sum_{l=1}^{n} I_{l} * w_{i}
$$

In correlation with that, bilateralism scope assessment $(B S)$ is the sum of the multiplication of bilateral areas assessment and their weights (equation 8).

$$
B S=\sum_{l=1}^{n} B A_{l} * w_{i}
$$


To ascertain whether the strategic partnership influences bilateralism, the impact can be checked through different criteria. In this research, the following criteria have been used: the trend growth of the period, the comparison of the end years of two sub periods (after and before signing an agreement) and the comparison of the trend growth of the sub periods in the second phase of the research. The period is divided in two sub periods: A-period (after signing an agreement) and B-period (before signing an agreement). Furthermore, trends of period and sub periods are calculated by equation 9 based on annual levels and number of years $(n)$.

$$
T G_{i}=\left(\sqrt[n]{\frac{\text { end year }}{\text { begin year }}}-1\right) * 100
$$

The comparison of the end years represents a relation between years (greater or smaller). If the end year of A-period is greater than the end year of B-period the strategic relationship has the impact on bilateralism. In addition, ratio of two trends $\left(T G_{a i}\right.$ - the trend growth of A-period and $T G_{b i}$ - the trend growth of B-period) is one of the possible ways to compare the trend growth of sub periods (Equation 10). If trend ratio $\left(T R_{i}\right)$ is greater than 1, the strategic relationship has the impact on bilateralism.

$$
T R_{i}=\frac{T G_{a i}}{T G_{b i}}
$$

There are numerous combinations of the criteria values (every criterion indicates the impact, some of criteria indicate the impact, etc.). The impact of the strategic partnership $\left(I_{m i}\right)$ on bilateralism can be determined based on the share of criteria, which indicates the impact (Equation 11),

$$
I_{m i}=\frac{n}{N}
$$

where $n$ is number of criteria, which indicates the impact and $N$ is number of criteria. The strength of the strategic partnership influence is divided in the following levels:

$$
\begin{array}{ll}
-I_{m i}=1 & \text { Perfect impact; } \\
-0.7 \leq I_{m i}<1 & \text { High impact; } \\
-0.3 \leq I_{m i}<0.7 & \text { Middle impact; } \\
-0<I_{m i}<0.3 & \text { Low impact; } \\
-l i=0 & \text { No impact. }
\end{array}
$$

The methodology enables the achievement of the research goal and application on the practical case. 


\section{Case study: the Republic of Serbia and its strategic partnerships}

Bearing in mind that bilateralism is the relation between two nations and a general number of nations in the world, it is possible to make more than 18,000 bilateral relationships. However, the number of relationships is significantly smaller between strategic partners, but the total number of signed strategic partnership agreements is unknown. In that sense, the research has been carried out on the case of the Republic Serbia (hereafter: Serbia). Serbia has signed the strategic partnership with six countries (Min17):

- the Republic of Azerbaijan (hereafter: Azerbaijan) - agreement signed in 2013;

- the People's Republic of China (hereafter: China) - agreement signed in 2013;

- the French Republic (hereafter: France) - agreement signed in 2011;

- the Italian Republic (hereafter: Italy) - agreement signed in 2009;

- the Russian Federation (hereafter: Russia) - agreement signed in 2013;

- The United Arab Emirates (hereafter: UAE) - agreement signed in 2013.

The relationship between countries includes numerous areas. Bearing in mind a large number of countries and areas, the research has been limited on the economic area and the impact of strategic partnership has been examined on the example of the Serbia's economic area and its indicators. According to the comprehensive process (Kankaraš, et al., 2017), in the first step an expert group of 15 specialists (employed in Serbian governmental bodies) have suggested the indicators, which are important to assess the level of economic area. They have proposed the following indicators:

- the total export from the Republic of Serbia to strategic partners (hereafter: export);

- the total import from the Republic of Serbia to strategic partners (hereafter: import);

- the total trade between the Republic of Serbia and its strategic partners (hereafter: total trade);

- the total external trade balance between the Republic of Serbia and its strategic partners (hereafter: trade balance);

- the total trade share of gross domestic product (hereafter: share of GDP);

- the total number of tourists from Serbian strategic partners (hereafter: number of tourists).

According to individual experts' opinion, the average mutual influence matrix of economic area indicators is created by applying equation 1 and formed by equation 2 (Table 1).

Table 1 - The average mutual influence matrix

\begin{tabular}{|c|r|r|r|r|r|r|}
\hline Indicator & Export & \multicolumn{1}{|c|}{ Import } & \multicolumn{1}{|c|}{$\begin{array}{c}\text { Total } \\
\text { trade }\end{array}$} & $\begin{array}{c}\text { Trade } \\
\text { balance }\end{array}$ & $\begin{array}{c}\text { Share of } \\
\text { GDP }\end{array}$ & $\begin{array}{c}\text { Number of } \\
\text { tourists }\end{array}$ \\
\hline Export & 0.00 & 0.07 & 0.07 & 0.07 & 0.07 & 0.07 \\
\hline Import & 0.07 & 0.00 & 0.07 & 0.07 & 0.07 & 0.07 \\
\hline Total trade & 0.21 & 0.21 & 0.00 & 0.21 & 0.29 & 0.07 \\
\hline
\end{tabular}




\begin{tabular}{|c|c|c|c|c|c|c|}
\hline $\begin{array}{c}\text { Trade bal- } \\
\text { ance }\end{array}$ & 0.21 & 0.21 & 0.21 & 0.00 & 0.21 & 0.07 \\
\hline $\begin{array}{c}\text { Share of } \\
\text { GDP }\end{array}$ & 0.21 & 0.21 & 0.14 & 0.14 & 0.00 & 0.07 \\
\hline $\begin{array}{c}\text { Number of } \\
\text { tourists }\end{array}$ & 0.14 & 0.14 & 0.14 & 0.14 & 0.14 & 0.00 \\
\hline
\end{tabular}

The matrix of total relation between the indicators has been calculated by equation 3 . Bearing in mind that threshold value is $\mathbf{0 . 3 2 1}$ (calculated by equation 4 ) and that all elements of export and import are less than the threshold, these indicators should be rejected (Table 2).

Table 2 - The matrix of total relations

\begin{tabular}{|c|r|r|r|r|r|r|}
\hline Indicator & Export & \multicolumn{1}{|c|}{ Import } & \multicolumn{1}{|c|}{$\begin{array}{c}\text { Total } \\
\text { trade }\end{array}$} & $\begin{array}{c}\text { Trade } \\
\text { balance }\end{array}$ & $\begin{array}{c}\text { Share of } \\
\text { GDP }\end{array}$ & $\begin{array}{c}\text { Number of } \\
\text { tourists }\end{array}$ \\
\hline Export & 0.155 & 0.220 & 0.183 & 0.183 & 0.207 & 0.136 \\
\hline Import & 0.220 & 0.155 & 0.183 & 0.183 & 0.207 & 0.136 \\
\hline Total trade & 0.567 & 0.567 & 0.294 & 0.467 & 0.587 & 0.244 \\
\hline $\begin{array}{c}\text { Trade bal- } \\
\text { ance }\end{array}$ & 0.536 & 0.536 & 0.445 & 0.271 & 0.503 & 0.230 \\
\hline $\begin{array}{c}\text { Share of } \\
\text { GDP }\end{array}$ & 0.472 & 0.472 & 0.344 & 0.344 & 0.266 & 0.203 \\
\hline $\begin{array}{c}\text { Number of } \\
\text { tourists }\end{array}$ & 0.413 & 0.413 & 0.343 & 0.343 & 0.388 & 0.133 \\
\hline
\end{tabular}

In the opinion of the experts, four indicators are significant for the assessment of economic area level. Considering that the sum of the indicators level and their weights multiplication represents area level, the levels of indicators have been determined on the basis of the data of Statistical Office of the Republic of Serbia (Statistical Office, 20062017) for every country (strategic partner) and all partners together in the period of 12 years (2006-2017) by equation 6 (Table 3 ).

Table 3 - The levels of indicators

\begin{tabular}{|l|l|l|l|l|l|l|l|l|l|l|l|l|}
\hline \multicolumn{1}{|c}{ Indicator } & 2006 & 2007 & 2008 & 2009 & 2010 & 2011 & 2012 & 2013 & 2014 & 2015 & 2016 & 2017 \\
\hline $\begin{array}{l}\text { Total trade with } \\
\text { Azerbaijan }\end{array}$ & 0.213 & 0.213 & 0.213 & 0.213 & 0.386 & 0.316 & 1.150 & 1.731 & 0.642 & 0.213 & 0.213 & 0,228 \\
\hline $\begin{array}{l}\text { Total trade with } \\
\text { China }\end{array}$ & 0.358 & 0.762 & 0.879 & 0.462 & 0.637 & 0.760 & 0.825 & 0.826 & 0.895 & -0.464 & -0.440 & 1,451 \\
\hline
\end{tabular}


The importance of a strategic partnership for bilateral relations

\begin{tabular}{|c|c|c|c|c|c|c|c|c|c|c|c|c|}
\hline Indicator & 2006 & 2007 & 2008 & 2009 & 2010 & 2011 & 2012 & 2013 & 2014 & 2015 & 2016 & 2017 \\
\hline $\begin{array}{l}\text { Total trade with } \\
\text { France }\end{array}$ & 0.111 & 0.438 & 0.653 & -0.063 & 0.136 & 0.030 & 0.229 & 0.539 & 0.699 & 1.217 & 1.511 & 1,516 \\
\hline Total trade with Italy & 0.118 & 0.227 & 0.193 & -0.095 & 0.095 & 0.168 & 0.334 & 1.029 & 1.110 & 1.129 & 1.194 & 1,151 \\
\hline $\begin{array}{l}\text { Total trade with } \\
\text { Russia }\end{array}$ & 0.687 & 0.723 & 1.352 & -0.571 & 0.366 & 0.792 & 0.599 & 0.274 & 0.900 & 0.304 & 0.076 & 0,331 \\
\hline Total trade with UAE & 0.238 & 0.341 & 0.360 & 0.087 & 0.334 & 0.192 & 0.460 & 0.319 & 0.423 & 0.858 & 1.887 & 1.473 \\
\hline Total trade & 0.086 & 0.422 & 0.660 & -0.462 & 0.105 & 0.337 & 0.505 & 1.082 & 1.379 & 0.661 & 0.727 & 1.238 \\
\hline $\begin{array}{l}\text { Trade balance } \\
\text { with Azerbaijan }\end{array}$ & 0.213 & 0.213 & 0.213 & 0.213 & 0.386 & 0.316 & 1.150 & 1.731 & 0.642 & 0.213 & 0.213 & 0.228 \\
\hline $\begin{array}{l}\text { Trade balance } \\
\text { with China }\end{array}$ & 0.618 & 0.225 & 0.112 & 0.534 & 0.362 & 0.255 & 0.177 & 0.180 & 0.123 & 1.462 & 1.451 & -0.353 \\
\hline $\begin{array}{l}\text { Trade balance } \\
\text { with France }\end{array}$ & 0.716 & -0.042 & -0.502 & 0.175 & 0.606 & 0.669 & 0.386 & 0.396 & 1.153 & 1.212 & 0.731 & 1.058 \\
\hline $\begin{array}{l}\text { Trade balance } \\
\text { with Italy }\end{array}$ & 0.411 & 0.030 & -0.212 & 0.035 & 0.519 & 0.353 & 0.084 & 0.872 & 1.146 & 1.169 & 1.093 & 0.865 \\
\hline $\begin{array}{l}\text { Trade balance } \\
\text { with Russia }\end{array}$ & -0.116 & -0.027 & -0.331 & 0.490 & 0.370 & 0.392 & 0.803 & 1.162 & 0.780 & 0.848 & 1.128 & 1.175 \\
\hline $\begin{array}{l}\text { Trade balance } \\
\text { with UAE }\end{array}$ & 0.238 & 0.341 & 0.360 & 0.087 & 0.334 & 0.192 & 0.460 & 0.319 & 0.423 & 0.858 & 1.887 & 1.473 \\
\hline $\begin{array}{l}\text { Total trade } \\
\text { balance }\end{array}$ & 0.247 & -0.015 & -0.288 & 0.334 & 0.396 & 0.311 & 0.380 & 0.795 & 0.714 & 1.266 & 1.361 & 0.958 \\
\hline $\begin{array}{l}\text { Share of GDP - } \\
\text { Azerbaijan }\end{array}$ & 0.211 & 0.211 & 0.211 & 0.211 & 0.388 & 0.315 & 1.166 & 1.720 & 0.646 & 0.211 & 0.211 & 0.226 \\
\hline $\begin{array}{l}\text { Share of GDP - } \\
\text { China }\end{array}$ & 0.443 & 0.803 & 0.845 & 0.468 & 0.638 & 0.743 & 0.824 & 0.788 & 0.883 & -0.477 & -0.458 & 1.416 \\
\hline $\begin{array}{l}\text { Share of GDP - } \\
\text { France }\end{array}$ & 0.376 & 0.551 & 0.590 & -0.109 & 0.100 & -0.068 & 0.194 & 0.450 & 0.704 & 1.257 & 1.454 & 1.471 \\
\hline $\begin{array}{l}\text { Share of GDP - } \\
\text { Italy }\end{array}$ & 0.232 & 0.262 & 0.142 & -0.122 & 0.076 & 0.134 & 0.328 & 1.013 & 1.145 & 1.146 & 1.145 & 1.071 \\
\hline $\begin{array}{l}\text { Share of GDP - } \\
\text { Russia }\end{array}$ & 1.072 & 0.837 & 1.175 & -0.473 & 0.384 & 0.719 & 0.584 & 0.180 & 0.833 & 0.251 & -0.061 & 0.098 \\
\hline $\begin{array}{l}\text { Share of GDP - } \\
\text { UAE }\end{array}$ & 0.248 & 0.349 & 0.355 & 0.076 & 0.335 & 0.184 & 0.465 & 0.313 & 0.424 & 0.871 & 1.881 & 1.466 \\
\hline $\begin{array}{l}\text { Total share of } \\
\text { GDP }\end{array}$ & 0.397 & 0.547 & 0.581 & -0.536 & 0.077 & 0.279 & 0.508 & 1.023 & 1.442 & 0.616 & 0.565 & 1.115 \\
\hline $\begin{array}{l}\text { Number of tourists } \\
\text { from Azerbaijan }\end{array}$ & 0 & 0 & 0 & 0 & 0 & 0 & 0 & 0 & 0 & 0 & 0 & 0 \\
\hline $\begin{array}{l}\text { Number of tourists } \\
\text { from China }\end{array}$ & 0.102 & 0.102 & 0.102 & 0.102 & 0.102 & 0.372 & 0.476 & 0.552 & 0.848 & 1.209 & 1.533 & 1.944 \\
\hline $\begin{array}{l}\text { Number of tourists } \\
\text { from France }\end{array}$ & -0.305 & 0.315 & 0.067 & 0.093 & 0.309 & 0.291 & 0.534 & 0.717 & 1.021 & 1.186 & 1.271 & 1.388 \\
\hline $\begin{array}{l}\text { Number of tourists } \\
\text { from Italy }\end{array}$ & -0.470 & 0.215 & 0.455 & 0.258 & 0.022 & 0.317 & 1.264 & 0.717 & 0.908 & 0.789 & 1.025 & 1.108 \\
\hline $\begin{array}{l}\text { Number of tourists } \\
\text { from Russia }\end{array}$ & -0.127 & 0.024 & 0.032 & 0.077 & 0.234 & 0.364 & 0.597 & 1.012 & 1.285 & 0.960 & 1.043 & 1.163 \\
\hline $\begin{array}{l}\text { Number of tourists } \\
\text { from UAE }\end{array}$ & 0 & 0 & 0 & 0 & 0 & 0 & 0 & 0 & 0 & 0 & 0 & 0 \\
\hline $\begin{array}{l}\text { Total number of } \\
\text { tourists }\end{array}$ & -0.223 & 0.094 & 0.117 & 0.096 & 0.149 & 0.335 & 0.719 & 0.836 & 1.118 & 1.041 & 1.218 & 1.560 \\
\hline
\end{tabular}


As shown in Table 3, the levels of indicators are different by years and countries. Some of them are below the expected minimum, but some of them are higher than the anticipated maximum. In addition, there were no tourists from Azerbaijan and UAE in the analysed period, so indicator for those countries is undefined. In that sense and based on the comprehensive process indicators, weights have been calculated by equation 4 :
- total trade
0.295
- trade balance
0.268
- share of GDP
0.214
- number of tourists
0.223

Based on indicators levels and their weights the level of economic area by years has been determined by equation 7 (Table 4).

Table 4 - The level of economic area

\begin{tabular}{|l|l|l|l|l|l|l|l|l|l|l|l|l|}
\hline \multicolumn{1}{|c|}{ Indicator } & $\mathbf{2 0 0 6}$ & $\mathbf{2 0 0 7}$ & $\mathbf{2 0 0 8}$ & $\mathbf{2 0 0 9}$ & $\mathbf{2 0 1 0}$ & $\mathbf{2 0 1 1}$ & $\mathbf{2 0 1 2}$ & $\mathbf{2 0 1 3}$ & $\mathbf{2 0 1 4}$ & $\mathbf{2 0 1 5}$ & $\mathbf{2 0 1 6}$ & $\mathbf{2 0 1 7}$ \\
\hline Total trade & 0.007 & 0.075 & 0.122 & -0.102 & 0.011 & 0.058 & 0.091 & 0.207 & 0.267 & 0.260 & 0.280 & 0.332 \\
\hline Trade balance & 0.070 & -0.042 & -0.160 & 0.108 & 0.135 & 0.098 & 0.128 & 0.306 & 0.271 & 0.272 & 0.301 & 0.283 \\
\hline Share of BDP & 0.055 & 0.082 & 0.087 & -0.107 & 0.000 & 0.035 & 0.075 & 0.165 & 0.238 & 0.224 & 0.192 & 0.239 \\
\hline $\begin{array}{l}\text { Number of } \\
\text { tourists }\end{array}$ & -0.036 & 0.019 & 0.023 & 0.020 & 0.029 & 0.061 & 0.128 & 0.148 & 0.198 & 0.184 & 0.215 & 0.348 \\
\hline $\begin{array}{l}\text { Economic } \\
\text { area }\end{array}$ & $\mathbf{0 . 0 9 7}$ & $\mathbf{0 . 1 3 3}$ & $\mathbf{0 . 0 7 3}$ & $-\mathbf{0 . 0 8 2}$ & $\mathbf{0 . 1 7 5}$ & $\mathbf{0 . 2 5 2}$ & $\mathbf{0 . 4 2 2}$ & $\mathbf{0 . 8 2 6}$ & $\mathbf{0 . 9 7 3}$ & $\mathbf{0 . 9 4 1}$ & $\mathbf{0 . 9 8 9}$ & $\mathbf{1 . 2 0 1}$ \\
\hline
\end{tabular}

In accordance with the methodology, ascertainment of the strategic partnership influence on economic area has been checked through three criteria: the trend growth of the period, the comparison of the end years and the comparison of the trend growth of A-period and Bperiod. Bearing in mind that four of six strategic agreements were signed in 2013, B-period covers seven years (2006-2012) and A-period includes five years (2013-2017). The results, which have been calculated by equations 9-11, are presented in Table 5.

Table 5 - Trend growth and trend ratio of economic area and its indicators

\begin{tabular}{|c|c|c|c|c|c|c|c|c|}
\hline \multirow[t]{2}{*}{ Indicator } & \multirow{2}{*}{$\begin{array}{l}\text { The } \\
\text { trend } \\
\text { growth } \\
\text { of the } \\
\text { period }\end{array}$} & \multicolumn{3}{|c|}{$\begin{array}{l}\text { The comparison of end } \\
\text { years of sub periods }\end{array}$} & \multicolumn{4}{|c|}{$\begin{array}{l}\text { The comparison of trends growth o } \\
\text { sub periods }\end{array}$} \\
\hline & & $\begin{array}{c}\text { A- } \\
\text { period }\end{array}$ & $\begin{array}{l}\text { B- } \\
\text { period }\end{array}$ & Relation & A-period & B-period & Trend & atio \\
\hline Total trade & $37.33 \%$ & 0.332 & 0.091 & $A>B$ & $9.91 \%$ & $43.26 \%$ & 0.229 & $<1$ \\
\hline Trade balance & $12.30 \%$ & 0.283 & 0.128 & $A>B$ & $-1.60 \%$ & $8.94 \%$ & -0.179 & $<1$ \\
\hline Share of BDP & $12.93 \%$ & 0.239 & 0.075 & $A>B$ & $7.73 \%$ & $4.34 \%$ & 1.779 & $>1$ \\
\hline $\begin{array}{l}\text { Number of } \\
\text { tourists }\end{array}$ & $20.84 \%$ & 0.348 & 0.128 & $A>B$ & $18.57 \%$ & $19.95 \%$ & 0.931 & $<1$ \\
\hline $\begin{array}{l}\text { Economic } \\
\text { area }\end{array}$ & $23.31 \%$ & 1.201 & 0.422 & $A>B$ & $7.77 \%$ & $23.34 \%$ & 0.333 & $<1$ \\
\hline
\end{tabular}


Two criteria indicate the impact of strategic partnership on economic area (the trend growth of the period and the comparison of end years of sub periods), and one criterion indicates the lack of impact (the comparison of trend growth of sub periods). The impact of strategic partnership on economic area is determined by equation 11 and it amounts 0.67 , which implies a middle direct influence.

\section{Research Results}

Bearing in mind that the research has been carried out through two phases, on the foundation of their outcomes, specific (stages outcomes) and general results (process outcomes) of the research can be noticed. The outcomes of the stages are the validation of the comprehensive process and its application to bilateralism scope assessment. Regardless of the fact that the comprehensive process has been applied to assess the economic area, it can be concluded that the process can be implemented for bilateralism scope appraisement.

The specific results are important, but the general result of research is more important. In accordance with the previous one, there are two general outcomes:

- the model of assessment of the strategic partnership impact on bilateralism;

- conclusion about the impact of strategic partnership on bilateralism.

The synthesis of phases has created a new model - the model of assessment of the strategic partnership impact on bilateralism. In fact, the model is the comprehensive model upgraded by new stage, the impact ascertainment. This impact is additional criterion for bilateralism assessment and spotting actions to improve bilateralism (Figure 4). Practically, a strategic partnership is additional criterion for bilateralism assessment.

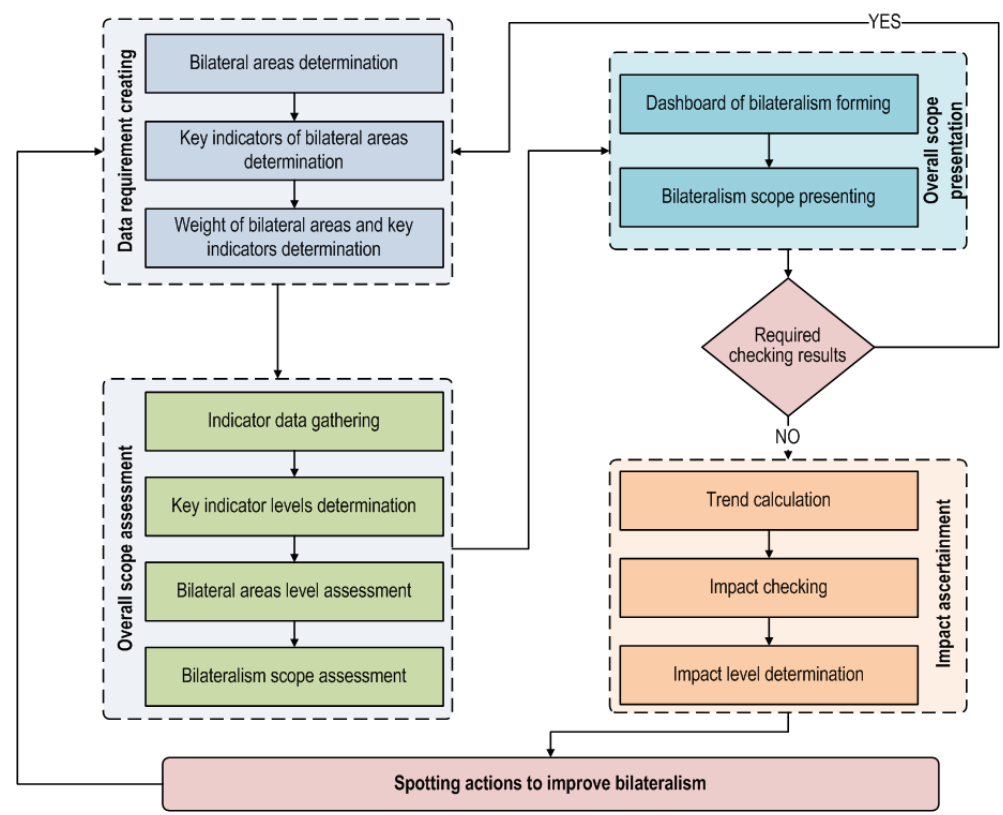

Figure 4 - The model of strategic partnership impact assessment on bilateralism 
On the basis of the research results, it can be concluded that a strategic partnership has an impact on bilateralism, but the level of that influence can vary. According to the research results, the focus of bilateralism is different. For instance, the focus of cooperation between Serbia and China, France and Italy in economic area is total trade and tourism, between Serbia and Russia is trade balance and tourism, etc. In addition, the highest level of cooperation between Serbia and Azerbaijan in economic area was in 2013 (the year when the agreement was signed), but the total level is "low impact".

In accordance with the abovementioned, there are two reasons for the different levels of the strategic partnership - strategic partner (certain country) and bilateralism area. Every country defines significant areas and the desired level of cooperation. As a final point, the level of strategic partnership impact on bilateralism varies from zero to perfect level depending on countries, but the total impact is middle and strategic partnership has the impact on bilateralism.

\section{Conclusion}

There are different kinds of cooperation between countries. One of the modes of cooperation is the strategic partnership and it has impact on bilateralism in various areas. The purpose of this paper is to determine the way to assess the impact of strategic partnership on bilateralism and to check that impact. In that sense, the research has been organized, and the comprehensive process and different methods have been applied.

The impact has been checked in the case of strategic partnerships signed between Serbia and six countries (Azerbaijan, China, France, Italy, Russia and UAE). There are two main research results: the model of strategic partnership impact assessment has been created and the impact of strategic partnership on bilateralism has been confirmed.

The future research should consider the determination of indicators and areas weights and increase objectivity. In addition, the process of assessment should automate and decrease the possibility of mistakes.

\section{Bibliography}

[1] Bilateral issues with foreign countries [Online] // Ministry of Foreign Affairs of the Republic of Serbia. - September 14, 2017. - http://www.mfa.gov.rs/en/foreign-policy/bilateral-issues.

[2] Blum Gabriella Bilateralism, Multilateralism, and the Architecture of International Law [Journal] // Harvard International Law Journal. - 2008. - 2 : Vol. 49. - pp. 323-379.

[3] Cudworth Erika, Hall Timothy and McGovern John The Modern State: Theories and Ideologies [Book]. - Edinburgh : Edinburgh University Press, 2007. - ISBN-13: 978-0748621767.

[4] Djankov Simeon and Miner Sean China's Belt and Road Initiative: Motives, Scope, and Challenges [Book]. - [s.I.] : Peterson Institute for International Economics, 2016.

[5] Ejdys Joanna New Silk Road - a Weak or a Strong Signal? [Conference] // 7th International Conference on Engineering, Project, and Production Management / ed. Elsvier. - 2016. - pp. 182-188.

[6] Gilson Julie The Strategic Partnership Agreement between the EU and Japan: the pitfalls of path dependency? [Journal] // Journal of European Integration. - [s.I.] : Taylor\&Francis, 2016. - 7 : Vol. 38. - pp. 791-806. - Print ISSN: 0703-6337 Online ISSN: 1477-2280.

[7] Gorard S and Gorard J What to do instead of significance testing? Calculating the 'number of counterfactual cases needed to disturb a finding' [Journal] // International Journal of Social Research Methodology. - 2016. - pp. 481-490. 
[8] Kankaraš Milan Unapredjenje funkcije upravljanja ljudskim resursima u sistemu odbrane (Improving the functions of the defence human resource management) [Report] : PhD Thesis / University of Defence, Military Academy. - Belgrade : [s.n.], 2016.

[9] Kankaraš Milan, Radović Blažo and Petrović Ivan Assessment of the Belt and Road Inititative's Bilateralism [Conference] // Working paper 2017/03. - Budapest: China-CEE Institute, 2017. - ISSN: 2560-1628.

[10] Kaplan Robert and Norton David The Office of Strategy Management [Journal] // Harvard Business Review. - october 2005. - pp. 73-80.

[11] Kuhberger A, Fritz A and Schemdl T Publication bias in psychology [Journal] // PLoS one. 2014. - p. doi: $10.137 /$ journal.pome. 0105825.

[12] Mann Prem S. Introductory Statistics, eighth edition [Book]. - Hoboken, NJ : John Wiley \& Sons, Inc., 2013.

[13] Ministry of Defence [Online] // International military cooperation. - September 18, 2017. http://www.mod.gov.rs/eng/10069/medjunarodna-vojna-saradnja-10069.

[14] Ministry of foreign affairs [Online] // About the Ministry. - September 14, 2017. http://www.mfa.gov.rs/en/about-the-ministry/about-the-ministry.

[15] Moghaddam Naser Bagheri [et al.] Strategic Environment Analysis Using DEMATEL Method Thorogh Systematic Approach: Case Study of an Energy Research Institute in Iran [Journal] /I Management Science and Engineering. - 2010. - 4 : Vol. 4. - pp. 95-105.

[16] Nations United Member States of the United Nations [Online] // United Nations. - 2018. - August 14, 2018. - http://www.un.org/en/member-states/index.html.

[17] Niven P Balanced Scorecard step-by-step for government and non-profit agencies - 2nd edition [Book]. - [s.I.] : John Wiley \& Sons, Inc., 2008.

[18] Petrovic Dalibor [et al.] Objective Technology Selection Model: The Example of complex combat systems [Journal] // International Journal of Scientific \& Engineer. - 2017. - 3 : Vol. 8. - pp. 105-113. ISSN 2229-5518.

[19] Statistical office of the Republic of Serbia Statistical yearbooks of the Republic of Serbia [Book]. - Belgrade : Statistical office of the Republic of Serbia, 2006-2017. - ISSN 0354-4206.

[20] Strategic Partnership Agreement [Online] // Government of Canada. - November 14, 2016. April 2, 2018. - http://www.international.gc.ca/europe/assets/pdfs/can-eu-spa-text-eng.pdf.

[21] Sumrit Detcharat and Anuntavoranich Pongpun Using DEMATEL Method to Analyze the Casual Relations on Technological Innovation Capability Evaluation Factors in Thai Technology-Based Firms [Journal] // International Transaction Journal of Engineering, Management, \& Applied Sciences \& Technologies. - 2013. - pp. 81-103.

[22] Swaine Michael D Chinese Views and Commentary on the "One Belt, One Road" Initiative [Journal] // China Leadership Monitor. - 2016. - Vol. 47.

[23] Thompson Alexander and Verdier Daniel Political science [Online] // Multilateralism, Bilateralism and Regime Design. - Ohio State University. - September 14, 2017. https://politicalscience.osu.edu/faculty/athompson/Lateralisms.pdf.

[24] Wang Fei Analysis on the Regional Disparity in China and the Influential Factors [Journal] // American International Journal of Humanities and Social Science. - August 2016. - 4 : Vol. 2. - pp. 94-104.

[25] Wu W.-W. and Lee Y.-T. Developing global managers' competencies using the fuzzy DEMATEL method [Journal] // Expert Systems with Applications, 32 (2). - 2007. - pp. 499-507.

[26] Yang Y.P. [et al.] A novel hybrid MCDM model combined with DEMATEL and ANP with applications [Journal] // International Journal Operational Research. - 2008. - pp. 160-168.

[27] Yang Yabing, Liu ZiHao and Ma Dan Discussion about Promoting Regional Cooperation and Investment in Transportation Construction with the Countries of Southeast Asia under the Belt and Road Initiative [Conference] // The First International Symposium on Business Cooperation and Development in South-East and South Asia under B\&R Initiative (ISBCD-16). - [s.I.] : Atlantis Press, 2016. - pp. 87-90.

[28] Yi Wu Hung Constructing a strategy map for banking institutions with key performance indicators of the balanced scorecard [Journal] // Evaluation and program planing. - 2012. - Vol. 35. - pp. 303-320. 